DOI: $10.19195 / 0524-4544.326 .15$

JOANNA FILABER

ORCID: 0000-0002-3731-2679

Wyższa Szkoła Bankowa we Wrocławiu

\title{
Działania ratownicze ochotniczych straży pożarnych podczas akcji ratowniczych organizowanych i prowadzonych przez Państwową Straż Pożarną
}

\section{Wprowadzenie}

Zwiększająca się liczba (nie)bezpieczeństw naturalnych i cywilizacyjnych kształtuje bezpośrednio zmiany na poziomie akceptowalnego ryzyka przez indywidualnego beneficjenta bezpieczeństwa, co bezpośrednio determinuje polskiego ustawodawcę do dynamicznego wyznaczania nowych zadań publicznych w sferze bezpieczeństwa publicznego i dostosowania prawnych form działania do ich realizacji, w tym również dla ochrony przed pożarami, klęskami żywiołowymi i innymi miejscowymi zagrożeniami.

Transparentność badań prowadzonych na gruncie nauki prawa administracyjnego w zakresie kompetencji ustrojowych organów administracji publicznej oraz analizy taksonomii zmieniających się zagrożeń dokonywanych przez przedstawicieli nauk o bezpieczeństwie potwierdzają istnienie złożonego (z jednej strony) i otwartego (z drugiej) katalogu podmiotów odpowiedzialnych za ochronę bezpieczeństwa pożarowego ściśle związanego $\mathrm{z}$ bezpieczeństwem publicznym RP. Do podmiotów ustawowo odpowiedzialnych za ochronę przed (nie)bezpieczeństwami pożarowymi należy zaliczyć organy administracji publicznej i organy wyspecjalizowane ${ }^{1}$. Dodatkową grupę tworzą podmioty prywatne, które realizu-

${ }^{1}$ W katalogu tych podmiotów określanych przez przedstawicieli nauk o bezpieczeństwie jako służby i formacje mundurowe, a przez przedstawicieli socjologii jako grupy dyspozycyjne, należy wymienić przede wszystkim Państwową Straż Pożarną oraz inne formacje, które, realizując zadania 
jąc odmienne ustawowe zadania, pośrednio i fakultatywnie wpływają na ochronę przed pożarami ${ }^{2}$.

Należy także pamiętać o organizacjach i instytucjach społecznych oraz samych obywatelach, którzy, działając w grupach, jak na przykład członkowie ochotniczych straży pożarnych, w formie dobrowolnych stowarzyszeń realizują osobiste poczucie obywatelskiej odpowiedzialności za bezpieczeństwo indywidualne oraz bezpieczeństwo społeczeństwa lokalnego w ochronie przed pożarami i innymi miejscowymi zagrożeniami.

Celem opracowania jest przedstawienie prawnych aspektów warunkujących podejmowanie przez ochotnicze straże pożarne działań ratowniczych oraz wskazanie ich roli i znaczenia w organizowanych oraz prowadzonych przez Państwową Straż Pożarną akcjach ratowniczych dla zapewnienia bezpieczeństwa pożarowego w Rzeczypospolitej Polskiej. Problemy badawcze skupiają się na określeniu znaczenia takich pojęć, jak „działania ratownicze” i ,akcja ratownicza”, które bezpośrednio korelują z prawnymi podstawami realizowania zadań przez ochotnicze straże pożarne na terenie gminy i poza obszarem swojego działania na wezwanie Państwowej Straży Pożarnej, stosownie do regulacji art. 23 ustawy z dnia 24 sierpnia 1991 roku o ochronie przeciwpożarowej ${ }^{3}$.

W artykule zostanie podjęta próba odpowiedzi na następujące pytania: jakie są prawne uwarunkowania udziału strażaków ochotniczych straży pożarnych w akcjach ratowniczych organizowanych i prowadzonych przez Państwową Straż Pożarną?; jakie regulacje prawne determinują udział strażaków ochotników w krajowym systemie ratowniczo-gaśniczym?; czy każdy strażak ochotniczej straży pożarnej może uczestniczyć w akcji ratunkowej?; czy będące w obrocie prawnym definicje działań dla ochrony przeciwpożarowej składające się na szeroko pojęty krajowy system ratowniczo-gaśniczy są definicjami legalnymi z punktu widzenia prawnego?; jakie jest miejsce w prawnym aparacie pojęciowym ochotniczych służb pożarniczych funkcjonujących na terenie niemalże każdej gminy w RP? Ponadto badanie stanowi próbę odpowiedzi na pytanie, w jakim stopniu istniejące stosunki prawne w zakresie funkcjonowania ochotniczych straży pożarnych i ich udział w akcjach ratowniczych wpływają na zapewnienie bezpieczeństwa publicznego na terenie podstawowej jednostki samorządu terytorialnego.

w obszarze bezpieczeństwa publicznego, pośrednio kształtują poziom (nie)bezpieczeństwa pożarowego, i są nimi między innymi Policja, Straż Miejska, Straż Graniczna, Agencja Bezpieczeństwa Wewnętrznego, Służba Więzienna, Żandarmeria Wojskowa, Straż Łowiecka, Straż Ochrony Kolei, Państwowa Straż Rybacka, Straż Leśna, Państwowa Inspekcja Pracy.

${ }^{2}$ W obszarze bezpieczeństwa pożarowego jako jednego z filarów bezpieczeństwa publicznego należy wskazać na pomocniczą rolę, jaką odgrywa bezpieczeństwo prywatne realizowane przez firmy ochrony osób i mienia oraz służby porządkowe (na przykład organizatora imprezy masowej), które przez swoją subsydiarność warunkują pośrednio poziom samego bezpieczeństwa publicznego, w tym pożarowego podczas imprezy masowej bądź na chronionym terenie lub obiekcie.

3 Dz.U. z 2018 r. poz. 620 ze zm. 
Ze względu na obszerność problemu badawczego analiza objęta przedmiotowym artykułem będzie ograniczona do udziału ochotniczych straży pożarnych $\mathrm{w}$ akcjach ratowniczych $\mathrm{w}$ zakresie empirycznych eksplikacji w uwarunkowaniach materialnego prawa administracyjnego.

\section{Zadania Państwowej Straży Pożarnej w zakresie ochrony przeciwpożarowej na terenie Rzeczypospolitej Polskiej}

Państwowa Straż Pożarna na mocy ustawy z dnia 24 sierpnia 1991 roku o Państwowej Straży Pożarnej (Dz.U. z 2017 r. poz. 1204 ze zm.) ${ }^{4}$ powstała jako zawodowa i umundurowana formacja wyposażona w specjalistyczny sprzęt, bez której niemożliwe byłoby dbanie o bezpieczeństwo lokalne w zakresie ochrony przeciwpożarowej.

Celem działania funkcjonariuszy pożarnictwa jest walka z pożarami, klęskami żywiołowymi i innymi miejscowymi zagrożeniami, które należy bezpośrednio interpretować przez zastosowanie narzędzi wykładni rozszerzającej, w odniesieniu do faz ochrony przeciwpożarowych wyodrębnionych na gruncie art. 1 w związku z art. 2 pkt 1a-b ustawy o ochronie przeciwpożarowej, to jest od zapobiegania powstawania i rozprzestrzeniania się pożaru, klęski żywiołowej lub innego miejscowego zagrożenia, dalej do rozpoznawania miejscowych (nie)bezpieczeństw oraz zapewnienia sił i środków na ich reagowanie, aż do właściwego prowadzenia akcji ratowniczych przy bezpośredniej współpracy z ochotniczymi

4 Ustawa z dnia 24 sierpnia 1991 roku o Państwowej Straży Pożarnej obowiązuje w Rzeczypospolitej Polskiej od dnia 1 stycznia 1992 roku. Warto przypomnieć, że do dnia 1 stycznia 1992 roku na mocy dekretu z dnia 27 grudnia 1974 roku o służbie funkcjonariuszy pożarnictwa (Dz.U. Nr 50, poz. 321) zadania straży pożarnej, jako formacji mundurowej i specjalistycznej, wykonywała Zawodowa Straż Pożarna. Ponadto w zakresie organizacji ochrony przeciwpożarowej obowiązywała początkowo ustawa z dnia 4 lutego 1950 roku o ochronie przeciwpożarowej i jej organizacji (Dz.U. Nr 50, poz. 404), która we wszystkich województwach i powiatach utworzyła komendy straży pożarnych jako organów terenowych władz administracji państwowej, zob. szerzej E. Ura, System prawny ochrony przeciwpożarowej w PRL, Warszawa 1981. Trzeba zwrócić także uwagę na wprowadzaną w RP zasadę powszechnego obowiązku ochrony przeciwpożarowej, zapoczątkowaną pod rządami ustawy z dnia 13 kwietnia 1960 roku o ochronie przeciwpożarowej (Dz.U. Nr 20, poz. 120), a następnie poszerzoną przez ustawę z 12 czerwca 1975 roku o ochronie przeciwpożarowej (Dz.U. Nr 20, poz. 106), obowiązującą aż do 25 września 1991 roku, w ramach której dokonano rozszerzonej i pogłębionej zasady powszechnego obowiązku ochrony przeciwpożarowej w aspekcie zapobiegania pożarom i ich zwalczania na wszystkie osoby fizyczne i prawne, organy administracji państwowej, instytucje, organizacje społeczne i zawodowe. Zob. szerzej J. Kuczyński, Ustawa o ochronie przeciwpożarowej z komentarzem, Warszawa 1970, a w zakresie kolejnej nowelizacji ustawy z 1975 roku idem, Zapobieganie pożarom. Zagadnienia prawne, Warszawa 1979. 
służbami ratowniczymi, a także ze strażami innych państw. Określone cele działania są bezpośrednią implikacją ustawowo wyznaczonych zadań Państwowej Straży Pożarnej ${ }^{5}$ na gruncie ustawy o Państwowej Straży Pożarnej oraz ustawy o ochronie przeciwpożarowej, a także aktów wykonawczych do przedmiotowych ustaw pożarniczych.

Realizację zadań publicznych na rzecz ochrony przeciwpożarowej przez Państwową Straż Pożarną należy rozpatrywać w interakcji pięciu podstawowych obszarów działania systemu ratowniczo-gaśniczego ${ }^{6}$ : walki z pożarami, akcji ratowniczych, ratownictwa technicznego, chemicznego, ekologicznego i medycznego oraz czynności kontrolno-rozpoznawczych. Ponadto można wskazać na zadania dodatkowe Państwowej Straży Pożarnej, w kontekście walki z pożarami, do których należy ocena projektów budowlanych pod względem ochrony przeciwpożarowej oraz uczestniczenie w odbiorze obiektów do użytku ${ }^{7}$.

Punktem wyjścia do analizy obszarów działania straży zawodowej jest przedstawienie zakresu przedmiotowego pojęcia ochrony przeciwpożarowej na gruncie norm prawnych wyinterpretowanych $\mathrm{z}$ art. 1 ustawy o ochronie przeciwpożarowej z obowiązkowym uzupełnieniem o wykładnię językową z definicjami legalnymi z art. 2 pkt 1-3 powyższej ustawy, a następnie poszerzeniem o interpretację linii orzecznictwa sądowego ${ }^{8}$ jako nieformalnego źródło prawa w Rzeczypospo-

5 Do podstawowych zadań Państwowej Straży Pożarnej należy: rozpoznawanie zagrożeń pożarowych i innych miejscowych zagrożeń; organizowanie i prowadzenie akcji ratowniczych w czasie pożarów, klęsk żywiołowych lub likwidacji miejscowych zagrożeń; wykonywanie pomocniczych specjalistycznych czynności ratowniczych w czasie klęsk żywiołowych lub likwidacji miejscowych zagrożeń przez inne służby ratownicze; kształcenie kadr na potrzeby Państwowej Straży Pożarnej i innych jednostek ochrony przeciwpożarowej oraz powszechnego systemu ochrony ludności; nadzór nad przestrzeganiem przepisów przeciwpożarowych; prowadzenie prac naukowo-badawczych w zakresie ochrony przeciwpożarowej oraz ochrony ludności; współpraca z Szefem Krajowego Centrum Informacji Kryminalnych w zakresie niezbędnym do realizacji jego zadań ustawowych; współdziałanie ze strażami pożarnymi i służbami ratowniczymi innych państw oraz ich organizacjami międzynarodowymi na podstawie wiążących RP umów międzynarodowych oraz odrębnych przepisów, a ponadto realizacja innych zadań wynikających z wiążących RP umów międzynarodowych na zasadach i w zakresie w nich określonych.

${ }^{6}$ Klasyfikacja działań podejmowanych na rzecz bezpieczeństwa społeczności lokalnej w obszarze ochrony przeciwpożarowej znajduje się również w monografii A. Gumieniak, L. Owczarek, R. Mochocki, Bezpieczeństwo w wymiarze lokalnym. Wybrane obszary, red. M. Leszczyński, Warszawa 2013, s. 119-134. Zob. także A. Warmiński, Zadania i organizacja Państwowej Straży Pożarnej w zakresie ochrony przeciwpożarowej, „Doctrina Studia Społeczno-Polityczne” 2009, nr 6, s. 275-304. Należy polecić także W. Leśniakiewicz, Państwowa Straż Pożarna a Krajowy System Ratowniczo-Gaśniczy, Inowrocław 2010.

7 Zob. szerzej rozporządzenie Ministra Spraw Wewnętrznych z dnia 7 czerwca 2010 roku w sprawie ochrony przeciwpożarowej budynków, innych obiektów budowlanych i terenów (Dz.U. Nr 109, poz. 719).

8 Zob. szczególnie wyrok Sądu Najwyższego z dnia 13 lutego 1978 roku, sygn. akt IV KR 18/78, i aktualną do dziś interpretacją pojęcia ,pożar” oraz ukształtowaną interpretacją związku z niebezpieczeństwem przerzucania się ognia na inne przedmioty lub obiekty (OSNPG 1978, nr 7, poz. 80). 
litej Polskiej. Następnie trzeba zinterpretować pojęcia „zapobieganie powstawaniu i rozprzestrzenianiu się pożaru”, , „klęska żywiołowa"10 lub „inne miejscowe zagrożenie"11 na gruncie art. 2 pkt 1 i 2 ustawy o ochronie przeciwpożarowej z regulacją aktu wykonawczego, to jest § 13-14 rozporządzenia Ministra Spraw Wewnętrznych i Administracji z dnia 3 lipca 2017 roku w sprawie szczegółowej organizacji krajowego systemu ratowniczo-gaśniczego ${ }^{12}$, wobec braku przedmiotowych definicji legalnych w przepisach ustawy o Państwowej Straży Pożarnej. Ostatecznie nie można pominąć empirycznej i dychotomicznej analizy znaczeniowej terminu „klęska żywiołowa” na gruncie art. 3 ust. 1 pkt $1^{13}$ ustawy z dnia 18 kwietnia 2002 roku o stanie klęski żywiołowej (Dz.U. z 2017 r. poz. 1897) i art. 1 ustawy o ochronie przeciwpożarowej w kontekście znaczeniowym terminu „katastrofa naturalna"14 z ustawy o stanie klęski żywiołowej. Ponadto, uzupełniając badania tekstów prawnych, należy wskazać na definicyjne znaczenie pojęcia

W zakresie znaczenia art. 1 ustawy o ochronie przeciwpożarowej należy polecić jedyny komentarz do przedmiotowej ustawy autorstwa B. Kurzępy, Ustawa o ochronie przeciwpożarowej z komentarzem, Kraków-Tarnobrzeg 2010, i poprzednie wydanie pod tym samym tytułem z 2008 roku.

9 Przez zapobieżenie powstawaniu i rozprzestrzenianiu się pożaru, klęski żywiołowej lub innego miejscowego zagrożenia ustawodawca, w myśl art. 2 pkt 1 ustawy o ochronie przeciwpożarowej, rozumie: „zapewnienie koniecznych warunków ochrony technicznej nieruchomościom i ruchomościom, tworzenie warunków organizacyjnych i formalnoprawnych zapewniających ochronę ludzi i mienia, a także przeciwdziałających powstawaniu lub minimalizujących skutki pożaru, klęski żywiołowej lub innego miejscowego zagrożenia”.

10 Zwrot „klęska żywiołowa”, za B. Kurzępą, op. cit. s. 8, należy odczytywać, jako wielkie zniszczenie spowodowane działaniem żywiołu. Straty spowodowane wielkim pożarem (na przykład dużych obszarów leśnych czy pól uprawnych) na pewno będą zaliczane do klęski żywiołowej. Trudno jednakże przeprowadzić granicę, do której działanie ognia traktujemy jeszcze jako pożar, a od której pożar uważa się już za klęskę żywiołową. Należy podkreślić, że w tym znaczeniu nie jest mowa o klęsce żywiołowej z ustawy z dnia 18 kwietnia 2002 roku o stanie klęski żywiołowej, o czym szerzej w przypisie 13, lecz o zagrożeniu (na przykład pożar wielkoobszarowy czy powódź) niebędącym stanem nadzwyczajnym, ale powodującym znaczne straty osobowe, majątkowe i środowiskowe.

11 Pod pojęciem ,inne miejscowe zagrożenie" należy rozumieć zdarzenie wynikające z rozwoju cywilizacyjnego i naturalnego praw przyrody, niebędące pożarem ani klęską żywiołową, stanowiące zagrożenie dla życia, zdrowia, mienia lub środowiska, któremu zapobieżenie lub którego usunięcie skutków nie wymaga zastosowania nadzwyczajnych środków, w rozumieniu art. 2 pkt 2 ustawy o ochronie przeciwpożarowej.

12 Dz.U. z 2017 r. poz. 1319.

13 Ustawodawca pod pojęciem ,klęska żywiołowa”, jako jeden z trzech stanów nadzwyczajnych (obok stanu wyjątkowego i stanu wojennego), rozumie katastrofę naturalną lub awarię techniczną, których skutki zagrażają życiu lub zdrowiu dużej liczby osób, mieniu w wielkich rozmiarach albo środowisku na znacznych obszarach, a pomoc i ochrona mogą być skutecznie podjęte tylko przy zastosowaniu nadzwyczajnych środków, we współdziałaniu różnych organów i instytucji oraz specjalistycznych służb i formacji działających pod jednolitym kierownictwem.

14 Katastrofa naturalna jest to zdarzenie związane z działaniem sił naturalnych, w szczególności wyładowania atmosferyczne, wstrząsy sejsmiczne, silne wiatry, intensywne opady atmosferyczne, długotrwałe występowanie ekstremalnych temperatur, osuwiska ziemi, pożary, susze, powodzie, zjawiska lodowe na rzekach i morzu oraz jeziorach i zbiornikach wodnych, masowe występowanie 
„awaria techniczna”"15, aby wyraźnie postawić tezę, że w terminie „awaria techniczna” mieści się między innymi desygnat nazwy „inne miejscowe zagrożenie”, a w katastrofie naturalnej — „klęska żywiołowa” w rozumieniu ustawy o ochronie przeciwpożarowej.

Uszczegóławiając, przez walkę z pożarami należy rozumieć planowanie, organizowanie i realizację działań ratowniczych ${ }^{16}$ niezbędnych do ugaszenia pożaru, a także do zmniejszenia lub likwidacji zagrożenia pożarowego, które są prowadzone siłami i środkami podmiotów krajowego systemu ratowniczo-gaśniczego właściwymi ze względu na miejsce powstania pożaru, w myśl ust. $3 \mathrm{w}$ związku z ust. 2 § 13 rozporządzenia Ministra Spraw Wewnętrznych i Administracji w sprawie szczegółowej organizacji krajowego systemu ratowniczo-gaśniczego. Dodatkowo przez walkę z innymi klęskami żywiołowymi należy rozumieć, stosownie do brzmienia § 14 rozporządzenia wykonawczego z 2017 roku, planowanie, organizowanie i realizację działań ratowniczych niezbędnych do ratowania życia, zdrowia, mienia lub środowiska ${ }^{17}$.

szkodników, chorób roślin lub zwierząt albo chorób zakaźnych ludzi bądź działania innego żywiołu, w myśl art. 3 ust. 1 pkt 2 ustawy o stanie klęski żywiołowej.

15 Analiza pozytywnego ustawodawstwa, a szczególnie art. 3 ust. 1 pkt 3 ustawy o stanie klęski żywiołowej, prowadzi do wniosku, że pod pojęciem awarii technicznej w Rzeczypospolitej Polskiej należy rozumieć gwałtowne, nieprzewidziane uszkodzenie lub zniszczenie obiektu budowlanego, urządzenia technicznego lub systemu urządzeń technicznych powodujące przerwę w ich użyciu lub utratę ich właściwości.

16 Działania ratownicze niezbędne do ugaszenia pożaru, a także do zmniejszenia lub likwidacji zagrożenia pożarowego obejmują w szczególności: rozpoznanie i identyfikację zagrożenia; zabezpieczenie strefy działań ratowniczych, w tym wyznaczenie i oznakowanie strefy zagrożenia; włączanie lub wyłączanie instalacji, urządzeń i mediów mających wpływ na bezpieczeństwo zagrożonych lub poszkodowanych osób oraz na bezpieczeństwo ratowników, z wykorzystaniem zaworów lub bezpieczników będących na instalacji użytkowej obiektu objętego działaniem ratowniczym; priorytetowe wykonanie czynności umożliwiających: dotarcie i wykonanie dostępu do zagrożonych lub poszkodowanych osób wraz z przeprowadzeniem medycznych działań ratowniczych i ewakuację poza strefę zagrożenia, nadto przygotowanie dróg ewakuacji zagrożonych lub poszkodowanych osób oraz ratowników i zapewnienie bezpieczeństwa zagrożonym lub poszkodowanym osobom oraz ratownikom. Do działań tych należy również ewakuacja i ratowanie osób, a następnie zwierząt oraz ratowanie środowiska i mienia przed skutkami pożaru lub wybuchu; ocenę rozmiarów zagrożenia pożarowego lub wybuchowego i prognozowanie jego rozwoju; dostosowanie sprzętu oraz technik i środków gaśniczych oraz innych środków ratowniczych do rodzaju, skali i miejsca pożaru lub wybuchu; likwidację, ograniczenie lub zwiększenie strefy zagrożenia; aż po uruchamianie dodatkowych sił i środków podmiotów krajowego systemu ratowniczo-gaśniczego i oddymianie strefy zagrożenia.

17 Działania ratownicze podczas innych klęsk żywiołowych obejmują w szczególności: rozpoznanie i identyfikację zagrożenia; zabezpieczenie strefy działań ratowniczych; włączanie lub wyłączanie instalacji, urządzeń i mediów mających wpływ na bezpieczeństwo zagrożonych lub poszkodowanych osób oraz na bezpieczeństwo ratowników, z wykorzystaniem zaworów lub bezpieczników będących na instalacji użytkowej obiektu objętego działaniem ratowniczym. W obszarze tym należy wyróżnić priorytetowe wykonanie czynności umożliwiających dotarcie i wykonanie dostępu do zagrożonych lub poszkodowanych osób, wraz z przeprowadzeniem medycznych dzia- 
Odnosząc się do obowiązkowych zadań Państwowej Straży Pożarnej, należy wskazać na wykonywanie przez strażaków zawodowych czynności kontrolno-rozpoznawczych zarówno na podstawie własnego rocznego planu czynności kontrolno-rozpoznawczych, jak i w wyniku zlecenia starosty, polecenia sądu, Najwyższej Izby Kontroli, a także zgłoszenia przez zakład o zwiększonym albo dużym ryzyku wystąpienia awarii przemysłowej. W perspektywie zwiększenia ochrony przeciwpożarowej społeczeństwa lokalnego istotne znaczenie ma też kompetencja wójta (burmistrza, prezydenta miasta) w zakresie zawiadomienia między innymi Państwowej Straży Pożarnej o wykonywaniu działalności gospodarczej przez przedsiębiorcę powodującego zagrożenie życia, zdrowia, niebezpieczeństwa powstania szkód majątkowych w znacznych rozmiarach lub naruszenia środowiska w wyniku wykonywania tej działalności, w myśl art. 78 ustawy z dnia 2 lipca 2004 roku o swobodzie działalności gospodarczej ${ }^{18}$.

Jednym z podstawowych zadań Państwowej Straży Pożarnej, szczególnie istotnym w zakresie tematyki analizowanego artykułu, jest organizowanie i prowadzenie akcji ratowniczej w czasie pożarów, klęsk żywiołowych lub likwidacji miejscowych zagrożeń (szerzej o zakresie pojęciowym akcji ratowniczej, działań ratowniczych i samych czynności ratowniczych w punkcie czwartym artykułu). W tym miejscu szczególnie należy zauważyć, że funkcjonowanie Państwowej Straży Pożarnej oraz prowadzenie działań ratowniczych w czasie pożarów, klęsk żywiołowych lub likwidacji innych zdarzeń wynikających z rozwoju cywilizacyjnego i naturalnego jest prowadzone także $\mathrm{z}$ udziałem jednostek ochrony przeciwpożarowej, czyli z udziałem między innymi ochotniczych straży pożarnych, które - stosownie do brzmienia art. 23 ustawy o ochronie przeciwpożarowej — ustawowo zostały zobligowane do udziału w akcjach ratowniczych poza terenem własnego działania w przypadku wezwania Państwowej Straży Pożarnej. Należy wskazać, że w akcjach ratowniczych poza terenem własnego działania na wezwanie państwowej Straży Pożarnej mogą uczestni-

łań ratowniczych i ewakuację poza strefę zagrożenia, przygotowanie dróg ewakuacji zagrożonych lub poszkodowanych osób oraz ratowników, zapewnienie bezpieczeństwa zagrożonym lub poszkodowanym osobom oraz ratownikom. Zasięg likwidacji zagrożeń związanych z klęską żywiołową polega również na dostosowaniu sprzętu oraz technik ratowniczych do rozmiaru i rodzaju klęski żywiołowej; uruchamianie dodatkowych sił i środków podmiotów i ocenę rozmiarów powstałej klęski żywiołowej.

18 Dz.U. z 2017 r. poz. 2486 ze zm. Nota bene, w przypadku braku możliwości zawiadomienia organów administracji to wójt (burmistrz, prezydent miasta) może nakazać, w drodze decyzji z rygorem natychmiastowej wykonalności, wstrzymanie wykonywania działalności gospodarczej przedsiębiorcy na czas niezbędny, nie dłużej jednak niż trzy dni. Na gruncie regulacji procesowego prawa administracyjnego w rozumieniu art. $106 \S 1$ ustawy z dnia 14 czerwca 1960 r. Kodeks postępowania administracyjnego (Dz.U. z 2017 r. poz. 1257 ze zm.) decyzji, od której służy odwołanie, może być nadany rygor natychmiastowej wykonalności, gdy jest to niezbędne ze względu na ochronę zdrowia lub życia ludzkiego albo dla zabezpieczenia gospodarstwa narodowego przed ciężkimi stratami bądź też ze względu na inny interes społeczny lub wyjątkowo ważny interes strony. 
czyć także tak zwane lotniskowe służby ratowniczo-gaśnicze, które należą do jednostek ochrony przeciwpożarowej w rozumieniu art. 15 ustawy o ochronie przeciwpożarowej ${ }^{19}$.

\section{Zintegrowanie podmiotów ratowniczych w krajowy system ratowniczo-gaśniczy}

W Rzeczypospolitej Polskiej organizacja ochrony przeciwpożarowej realizowana jest przy pomocy krajowego systemu ratowniczo-gaśniczego będącego integralną częścią systemu bezpieczeństwa wewnętrznego państwa i podstawą ogólnokrajowego systemu ochrony ludności ${ }^{20}$. System obejmuje niezbędne środki techniczne, zasoby ludzkie, ich organizację, kierowanie, szkolenie i finansowanie. Podstawą prawną utworzenia i działania krajowego systemu ratowniczo-gaśniczego w RP jest ustawa o ochronie przeciwpożarowej wraz z aktem wykonawczym, czyli rozporządzeniem Ministra Spraw Wewnętrznych i Administracji z dnia 3 lipca 2017 roku w sprawie szczegółowej organizacji krajowego systemu ratowniczo-gaśniczego (Dz.U. z 2017 r. poz. 1319).

Krajowy system ratowniczo-gaśniczy utworzono na bazie jednostek organizacyjnych Państwowej Straży Pożarnej, ale w jego skład wchodzą również inne podmioty włączone na mocy porozumienia między właściwym komendantem powiatowym (miejskim) Państwowej Straży Pożarnej a podmiotem tworzącym daną jednostkę oraz tą jednostką, co zostało określone w treści rozporządzenia Ministra Spraw Wewnętrznych i Administracji z dnia 15 września 2014 roku w sprawie zakresu szczegółowych warunków i trybu włączania jednostek ochrony przeciwpożarowej do krajowego systemu ratowniczo-gaśniczego (Dz.U. poz. 1314) ${ }^{21}$. Zatem system ratowniczo-gaśniczy RP skupia jednostki ochrony przeciwpożarowej, inne służby, inspekcje, straże, instytucje oraz podmioty, które dobrowolnie

19 Zob. szerzej na temat charakteru prawnego działalności straży pożarnych na lotniskach pasażerskich w Polsce oraz wybranych stosunków prawnych w zakresie lotnictwa cywilnego J.S. Kierzkowska, Wybrane aspekty prawne działalności tzw. „lotniskowych straży pożarnych” dla zapewnienia bezpieczeństwa działalności lotniczej w zakresie lotnictwa cywilnego, [w:] Działalność lotnicza w Polsce, red. K. Biskup, Z. Bukowski, Bydgoszcz 2015, s. 137-149.

20 Tak też W. Lis, Bezpieczeństwo wewnętrzne i porzadek publiczny jako sfera działania administracji publicznej, Lublin 2015, s. 321. Zob. także G. Gola, Jednostki ochrony przeciwpożarowej w systemie bezpieczeństwa, [w:] Bezpieczeństwo wewnętrzne w działaniach terenowej administracji publicznej, red. A. Chajbowicz, T. Kocowski, Wrocław 2009; oraz J. Skoczylas, Prawo ratownicze, Warszawa 2007.

21 Pierwotnie zasady włączania do systemu regulowało rozporządzenie Ministra Spraw Wewnętrznych i Administracji z dnia 14 września 1998 roku w sprawie zakresu, szczegółowych warunków i trybu włączania jednostek ochrony przeciwpożarowej do krajowego systemu ratowniczogaśniczego (Dz.U. Nr 121, poz. 798), który utracił moc z dniem 17 października 2014 roku. 
w drodze umowy cywilnoprawnej zgodziły się współdziałać w akcjach ratowniczych. Ich udział może polegać na oddelegowaniu specjalistów, użyczeniu sprzętu, umożliwieniu czerpania wody, skorzystania z sieci łączności itp. ${ }^{22}$

Zgodnie $\mathrm{z}$ art. 14 ustawy o ochronie przeciwpożarowej działanie krajowego systemu ratowniczo-gaśniczy ma na celu ochronę najważniejszych wartości w postaci życia i zdrowia ludzi. Ponadto powołany został dla ochrony mienia, a także środowiska ${ }^{23}$. Wskazane cele ochronne krajowy system ratowniczo-gaśniczy ma osiągać poprzez walkę z pożarami lub innymi klęskami żywiołowymi, ratownictwo techniczne, ratownictwo chemiczne, ratownictwo ekologiczne, ratownictwo medyczne oraz współpracę z jednostkami systemu Państwowego Ratownictwa Medycznego oraz systemem powiadamiania ratunkowego.

Krajowy system ratowniczo-gaśniczy jest zorganizowany na trzech poziomach: krajowym, wojewódzkim i powiatowym. Na poziomie powiatowym (podstawowym) wykonuje się wszystkie elementarne zadania systemu związane z obszarem powiatu. Natomiast poziomy wojewódzki i krajowy pełnią rolę wspomagającą i koordynacyjną w sytuacjach wymagających użycia sił i środków spoza obszaru danego powiatu lub województwa. Należy też odnotować, że zadania krajowego systemu ratowniczo-gaśniczego na terenie powiatu i województwa wykonują odpowiednio starostowie i wojewodowie przy pomocy wojewódzkich i powiatowych zespołów zarządzania kryzysowego, zgodnie z treścią ustawy z dnia 26 kwietnia 2007 roku o zarządzaniu kryzysowym (Dz.U. z 2017 r. poz. ze zm.) w związku z art. 14 ust. 4 ustawy o ochronie przeciwpożarowej.

Organizatorem i organem kierowniczym krajowego systemu ratowniczo-gaśniczego na terenie kraju jest Komendant Główny Państwowej Straży Pożarnej, na terenie województwa — komendant wojewódzki Państwowej Straży Pożarnej, w powiecie — komendant powiatowy (miejski) Państwowej Straży Pożarnej. Szczególnie należy podkreślić, że na terenie województwa wojewoda, jako przedstawiciel Rady Ministrów w terenie, tworzy „narzędzia prawne” realizacji zadań systemu. Podstawą prawną działań wojewody jest art. 14 ust. 3 ustawy o ochronie przeciwpożarowej w związku z art. 22 pkt 2 ustawy z dnia 23 stycznia 2009 roku o wojewodzie i administracji rządowej w województwie (Dz.U. z 2017 r. poz. 2234 ze zm.). Samo zaś wykonanie przedmiotowej kompetencji przez wojewodę następuje przez wydanie aktów prawa miejscowego, jakimi są zarządzenia ${ }^{24}$.

22 B. Kurzępa, op. cit., s. 12.

23 Na temat podstaw prawnych Krajowego Systemu Ratowniczo-Gaśniczego zob. R. Budzisz, Ochrona przeciwpożarowa, [w:] Prawo administracyjne materialne, Z. Duniewska, B. JaworskaDębska, M. Stahl, Warszawa 2014, s. 701-702. Zob. też R. Grosset, Rola Krajowego Systemu Ratowniczo Gaśniczego w systemie państwa, Warszawa 2011; idem, Poziom Powiatowy Krajowego Systemu Ratowniczo-Gaśniczego, Warszawa 2013.

${ }^{24} \mathrm{Na}$ przykładzie województwa dolnośląskiego można wskazać uchwalone zarządzenia w obszarze przeciwpożarowym. Są to: zarządzenie nr 50/2008 Wojewody Dolnośląskiego z dnia 25 lutego 2008 roku w sprawie określenia zadań krajowego systemu ratowniczo-gaśniczego na terenie województwa dolnośląskiego i zarządzenie nr 51/2008 Wojewody Dolnośląskiego z dnia 25 lu- 
Analiza pozytywnego ustawodawstwa prowadzi do wniosku, że mimo wyodrębnienia jedynie trójstopniowej (powiatowej, wojewódzkiej i krajowej) struktury krajowego systemu ratowniczo-gaśniczego szczególnie istotna dla ochrony przeciwpożarowej obywatela RP jest koordynacja funkcjonowania tego systemu na poziomie podstawowej jednostki samorządu terytorialnego, gdzie zawsze powstaje (nie)bezpieczeństwo. Zatem w ramach zadań publicznych gminy i zakresu koordynowania przez wójta (burmistrza, prezydenta miasta) funkcjonowania krajowego systemu ratowniczo-gaśniczego należy podkreślić, że koordynacja ta powinna obejmować prognozowanie, rozpoznawanie i zwalczanie zagrożeń pożarów, klęsk żywiołowych lub innych miejscowych zagrożeń — dla ratowania życia, zdrowia, mienia lub środowiska. Przedmiotowy zakres koordynacji organ wykonawczy gminy wykonuje w ramach zadań własnych określonych ustawowo, szczególnie na podstawie art. 7 pkt 14 ustawy z dnia 8 marca 1990 roku o samorządzie gminnym (Dz.U. z 2018 r. poz. 994 ze zm.) oraz zadań zleconych. Kluczową kwestią jest oczywiście określenie przez wojewodę w formie zarządzenia zakresu przedmiotowej koordynacji przez wójta (burmistrza, prezydenta miasta) krajowego systemu ratowniczo-gaśniczego na terenie gminy.

\section{Działania ochotniczych straży pożarnych dla ochrony przed (nie)bezpieczeństwami pożarowymi i innymi zagrożeniami}

Ochotnicze straże pożarne w formie dobrowolnych stowarzyszeń realizują osobiste poczucie obywatelskiej odpowiedzialności za bezpieczeństwo indywidualne oraz bezpieczeństwo społeczeństwa lokalnego. Podstawą prawną utworzenia ochotniczej straży pożarnej jest ustawa z dnia 7 kwietnia 1989 roku Prawo o stowarzyszeniach (Dz.U. z 2017 r. poz. 210 ze zm.), która definiuje stowarzyszenie jako dobrowolne, samorządne, trwałe zrzeszenie o celach niezarobkowych, określające samodzielnie swoje cele, programy działania i struktury organizacyjne, a swoją działalność opiera na pracy społecznej swoich członków.

Trzeba zwrócić uwagę na treść art. 19 ust. 1a w związku z art. 15 pkt 6 i art. 16a ustawy o ochronie przeciwpożarowej, które wprost kształtują pozycję ochotniczej straży pożarnej w systemie bezpieczeństwa pożarowego jako filaru bezpieczeństwa publicznego RP, jako jednostkę umundurowaną, wyposażoną w specjalistyczny sprzęt, przeznaczoną w szczególności do walki z pożarami, klęskami żywiołowymi lub innymi miejscowymi zagrożeniami. Ochotnicze stra-

tego 2008 roku w sprawie określenia zakresu koordynowania przez wójta (burmistrza, prezydenta miasta) funkcjonowania krajowego systemu ratowniczo-gaśniczego na obszarze gminy. 
że pożarne są z mocy ustawy jednostką ochrony przeciwpożarowej w rozumieniu art. 15 pkt 6 ustawy o ochronie przeciwpożarowej. Funkcjonują na podstawie ustawę Prawo o stowarzyszeniach i zadania określają samodzielnie w formie statutu stowarzyszenia.

Należy jednak odnotować, że cała ochotnicza straż pożarna jest jednostką ochrony przeciwpożarowej z mocy ustawy o ochronie przeciwpożarowej, lecz ustawodawca dokonuje podziału strażaków ochotników na strażaków biorących bezpośredni udział $\mathrm{w}$ działaniach ratowniczych (w przedziale wiekowym od 18 do 65 roku życia) oraz pozostałych strażaków (na przykład młodzieżowe drużyny pożarnicze czy seniorów). Celem spełnienia obowiązku, z art. 19 ust. 1b w związku z art. 28 ust 6 ustawy o ochronie przeciwpożarowej, bezpośredniego udziału w działaniach ratowniczych przez strażaków ochotniczej straży pożarnej, w kryterium wiekowym niezbędna jest obligatoryjność utworzenia jednostki operacyjno-technicznej ochotniczej straży pożarnej przez zarząd.

Jednostka operacyjno-techniczna ochotniczej straży pożarnej działa na podstawie regulaminu organizacyjnego przygotowanego przez zarząd ochotniczej straży pożarnej i zatwierdzonego uchwałą przez radę gminy, która upoważnia wójta (burmistrza, prezydenta miasta) do jej wykonania. W aktualnym stanie prawnym tylko jednostka operacyjno-techniczna może prowadzić działania ratownicze $\mathrm{z}$ art. 22 ust. 1 ustawy i brać udział $\mathrm{w}$ akcjach ratowniczych organizowanych i kierowanych przez Państwową Straż Pożarną, w tym poza swoim terenem działania, w myśl art. 23 ustawy o ochronie przeciwpożarowej. Zapewnianie gotowości bojowej ochotniczym strażom pożarnym, w tym kosztów wyposażenia, utrzymania i wyszkolenia, zgodnie z w art. 32 ust. 2-3 ustawy o ochronie przeciwpożarowej, należy do ustawowych zadań gminy realizowanych przez wójtów (burmistrzów, prezydentów miast), których należy zobligować do zawierania dwustronnych porozumień z ochotniczą strażą pożarną w przedmiotowym zakresie.

\section{Akcja ratownicza, działania ratownicze i czynności ratownicze w ochronie przed (nie)bezpieczeństwami pożarowymi i innymi miejscowymi zagrożeniami}

W odniesieniu do pojęcia akcji ratowniczej należy wskazać, że przepisy ustawy o ochronie przeciwpożarowej nie wyjaśniają, jak należy rozumieć określenie „akcja ratownicza”. Dlatego też tę definicję trzeba odkodować z treści regulacji ustawy o Państwowej Straży Pożarnej. W myśl art. 7 pkt 1 ustawy o Państwowej Straży Pożarnej pod pojęciem akcji ratowniczych rozumie się działania ratow- 
nicze organizowane i kierowane przez Państwową Straż Pożarną. Trzeba jednak zwrócić uwagę, że organizowanie i prowadzenie akcji ratowniczej w brzmieniu art. 13 ust. 6 pkt 7 ustawy o Państwowej Straży Pożarnej jest zadaniem publicznym komendanta powiatowego (miejskiego) Państwowej Straży Pożarnej, który organizuje krajowy system ratowniczo-gaśniczy na terenie powiatu (art. 13 ust. 6 pkt 3 ustawy o ochronie przeciwpożarowej). Ponadto prowadzenie akcji ratowniczej jest zadaniem organu administracji zespolonej działającej na terenie powiatu oraz kompetencją, czyli właściwością organu administracji publicznej stopnia podstawowego Państwowej Straży Pożarnej. Dodatkowo w $§ 2$ pkt 5 rozporządzenia w sprawie szczegółowej organizacji krajowego systemu ratowniczo-gaśniczego ustawodawca wprowadził definicję legalną pojęcia „kierowanie działaniem ratowniczym", przez które należy rozumieć planowanie, organizowanie, nadzorowanie i koordynowanie działań ratowniczych w rozumieniu art. 2 pkt 2 ustawy o ochronie przeciwpożarowej.

W kontekście przygotowania budynku lub terenu do prowadzenia akcji ratowniczej należy podkreślić, że jest to obowiązek właściciela budynku lub terenu, wynikający art. 4 ust. 1 pkt 5 ustawy o ochronie przeciwpożarowej ${ }^{25}$. Analiza kolejnych uregulowań wskazuje, że obowiązkiem właścicieli, zarządców obiektów lub terenu jest też ustalenie sposobów postępowania na wypadek pożaru, klęski żywiołowej (w rozumieniu ustawy o stanie klęski żywiołowej) lub innego zagrożenia (na przykład powodzi, suszy, które nie są stanem nadzwyczajnym), w myśl art. 4 ust. 1 pkt 7 ustawy o ochronie przeciwpożarowej, co bezpośrednio uzasadnia kompetencje kontrolno-rozpoznawcze Państwowej Straży Pożarnej w zakresie projektów budowlanych i prawidłowego użytkowania obiektów i terenów.

W zakresie znaczenia pojęcia „działania ratownicze” należy wskazać, że ustawodawca w art. 2 pkt 2 ustawy o ochronie przeciwpożarowej zawarł definicję legalną terminu „działania ratownicze”. Mianowicie ilekroć jest mowa w ustawie o ochronie przeciwpożarowej o działaniach ratowniczych rozumie się przez to

25 W zakresie obowiązków właścicieli budynków należy powołać tezę z wyroku Naczelnego Sądu Administracyjnego w Warszawie z dnia 9 września 2003 roku, sygn. IV SA 3858/01, zgodnie z którą stosownie do treści art. 4 ust. 1 pkt 4 ustawy o ochronie przeciwpożarowej na właścicielu budynku ciąży obowiązek zapewnienia odpowiedniej ochrony przeciwpożarowej, a w szczególności przygotowanie budynku i terenu do prowadzenia akcji ratowniczej. Z przepisu tego wynika obowiązek zapewnienia odpowiedniego dojazdu do budynku dla samochodów straży pożarnej. Na kanwie rozpatrywanej sprawy Naczelny Sąd Administracyjny wskazał, że w art. 4 ust. 1 pkt 4 przedmiotowej ustawy nie znajduje się umocowanie do nałożenia na skarżącego obowiązku przestrzegania zakazu parkowania samochodów na drodze pożarowej, a kwestia egzekwowania tego obowiązku wobec osób łamiących ten zakaz należy do policji, a nie do właściciela budynku.

Dodatkowo w zakresie obowiązków zarządcy nieruchomości, w myśl tezy wyroku Wojewódzkiego Sądu Administracyjnego w Gliwicach z dnia 11 września 2008 roku, sygn. II SA/Gl 399/08, należy podnieść, że skoro spółka przejęła na siebie w drodze umowy obowiązek sprawowania zarządu, to w świetle art. 4 ust. 1a ustawy o ochronie przeciwpożarowej przejęła w zakresie oznaczonym w umowie odpowiedzialność za realizację obowiązków z zakresu ochrony przeciwpożarowej. 
każdą czynność podjętą w celu ochrony życia, zdrowia, mienia lub środowiska, a także likwidację przyczyn powstania pożaru, wystąpienia klęski żywiołowej lub innego miejscowego zagrożenia.

Wymienienie wszystkich pojedynczych czynności zawierających się w znaczeniu działań ratowniczych nie jest w praktyce możliwe i tym samym regulowanie prawne każdej czynności z obszaru działania ratowniczego nie ma uzasadnienia prawnego. Istotą jest ocena skuteczności całego zbioru działań ratowniczych w interakcji pięciu podstawowych obszarów działania i są nimi działania ratownicze podczas walki $\mathrm{z}$ pożarami ${ }^{26}$, działania ratownicze podczas ratownictwa technicznego ${ }^{27}$, ratownictwa chemicznego i ekologicznego ${ }^{28}$ oraz działania ratownicze $\mathrm{w}$ ratownictwie medycznym ${ }^{29}$ podejmowane przez jednostki ochrony

26 W zakresie walki z pożarami ustawodawca przewidział na bazie krajowego systemu ratowniczo-gaśniczego następujące etapy: planowanie, organizowanie i realizację działań ratowniczych niezbędnych do ugaszenia pożaru, a także do zmniejszenia lub likwidacji zagrożenia pożarowego lub wybuchowego. Ponadto w treści $\S 13$ ust. 2 rozporządzenia Ministra Spraw Wewnętrznych i Administracji w sprawie szczegółowej organizacji krajowego systemu ratowniczo-gaśniczego zawarty jest katalog działań ratowniczych podczas pożaru obejmujący w szczególności: 1) rozpoznanie i identyfikację zagrożenia; 2) zabezpieczenie strefy działań ratowniczych, w tym wyznaczenie i oznakowanie strefy zagrożenia; 3) włączanie lub wyłączanie instalacji, urządzeń i mediów mających wpływ na bezpieczeństwo zagrożonych lub poszkodowanych osób oraz na bezpieczeństwo ratowników, z wykorzystaniem zaworów lub bezpieczników będących na instalacji użytkowej obiektu objętego działaniem ratowniczym; 4) priorytetowe wykonanie czynności umożliwiających: a) dotarcie i wykonanie dostępu do zagrożonych lub poszkodowanych osób wraz z przeprowadzeniem medycznych działań ratowniczych i ewakuacji poza strefę zagrożenia, b) przygotowanie dróg ewakuacji zagrożonych lub poszkodowanych osób oraz ratowników, c) zapewnienie bezpieczeństwa zagrożonym lub poszkodowanym osobom oraz ratownikom; 5) ewakuację i ratowanie osób, a następnie zwierząt oraz ratowanie środowiska i mienia przed skutkami pożaru lub wybuchu; 6) ocenę rozmiarów zagrożenia pożarowego lub wybuchowego i prognozowanie jego rozwoju; 7) dostosowanie sprzętu oraz technik i środków gaśniczych i innych środków ratowniczych do rodzaju, skali i miejsca pożaru lub wybuchu; 8) likwidację, ograniczenie lub zwiększenie strefy zagrożenia; 9) uruchamianie dodatkowych sił i środków podmiotów ksrg; 10) oddymianie strefy zagrożenia.

$27 \mathrm{~W}$ zakresie ratownictwa technicznego działania ratownicze polegają na poszukiwaniu i dotarciu do zagrożonych lub poszkodowanych osób oraz zwierząt, a także zmniejszeniu lub likwidacji zagrożenia dla życia, zdrowia, mienia lub środowiska. Szczegółowy katalog piętnastu działań ratowniczych podczas ratownictwa technicznego zawartych jest $\mathrm{w} \S 15$ rozporządzenia Ministra Spraw Wewnętrznych i Administracji w sprawie szczegółowej organizacji krajowego systemu ratowniczo-gaśniczego.

28 Stosownie do brzmienia $\S 16$ rozporządzenia w sprawie szczegółowej organizacji krajowego systemu ratowniczo-gaśniczego w zakresie ratownictwa chemicznego i ekologicznego działania jednostek ochrony przeciwpożarowej skupionych w krajowy system ratowniczo-gaśniczy (jednostki organizacyjne Państwowej Straży Pożarnej są trzonem głównym systemu) obejmują: planowanie, organizowanie i realizację działań ratowniczych niezbędnych do zmniejszenia lub likwidacji bezpośrednich zagrożeń stwarzanych przez substancje niebezpieczne dla ludzi, zwierząt, środowiska lub mienia. Szczegółowy katalog przedmiotowych działań ratowniczych w ratownictwie chemicznym i ekologicznym zawarł ustawodawca w ust. $2 \S 16$ powyższego rozporządzenia.

29 Definicja medycznych działań ratowniczych (§ 2 pkt 6 rozporządzenia Ministra Spraw Wewnętrznych i Administracji z dnia 3 lipca 2017 roku w sprawie szczegółowej organizacji krajowego 
przeciwpożarowej. Warto dodać, że do podmiotów zobowiązanych do podjęcia działań ratowniczych, poza jednostkami ochrony przeciwpożarowej, należą osoby fizyczne, osoby prawne, organizacje i instytucje korzystające ze środowiska, budynku, obiektu lub terenu, stosownie do brzmienia art. 3 ust. 1 ustawy o ochronie przeciwpożarowej, a nadto właściciele budynków, obiektu budowlanego lub terenu, a nawet osoby postronne.

Działania ratownicze prowadzą jednostki ochrony przeciwpożarowej z art. 15 pkt 1-6 i 8 ustawy o ochronie przeciwpożarowej, między innymi jednostki organizacyjne Państwowej Straży Pożarnej i ochotnicze straże pożarne. Ważne jest, że obszar działania jednostek ochrony przeciwpożarowej nie jest ograniczony terytorialnie do granic gmin, powiatów i województw. Inaczej mówiąc, jednostki ochrony przeciwpożarowej mają ustawowy obowiązek uczestniczyć, na wezwanie Państwowej Straży Pożarnej, w działaniach ratowniczych poza terenem własnego działania.

Szczegółowe zasady kierowania i współdziałania jednostek ochrony przeciwpożarowej biorących udział w działaniu ratowniczym reguluje rozporządze$n^{30}{ }^{30}$. Samym zaś kierowaniem działań ratowniczych zajmuje się jednoosobowo osoba uprawniona, będąca kierującym działaniem ratowniczym ${ }^{31}$, na podstawie art. 25 ustawy o ochronie przeciwpożarowej w związku z rozporządzeniem Rady Ministrów z dnia 4 lipca 1992 roku w sprawie zakresu i trybu korzystania z praw przez kierującego działaniem ratowniczym (Dz.U. Nr 54, poz. 259).

Należy przypomnieć, że kierowanie działaniem ratowniczym rozpoczyna się z chwilą przybycia na miejsce zdarzenia pierwszych sił i środków podmiotów krajowego systemu ratowniczo-gaśniczego, a kończy z chwilą wykonania tych działań oraz przekazania terenu akcji, obiektu lub mienia. W obszarze organizacyjnym ustawodawca dokonał trójstopniowego podziału poziomów działań ra-

systemu ratowniczo-gaśniczego) wraz z katalogiem podejmowanych czynności w zakresie planowania, organizowania i realizacji medycznych działań składa się całościowo na ratownictwo medyczne w ramach Krajowego Systemu Ratowniczo-Gaśniczego, którego działaniami ratowniczymi do czasu przybycia na miejsce zdarzenia zespołu ratownictwa medycznego lub lotniczego zespołu ratownictwa medycznego koordynuje osoba posiadająca kwalifikacje niezbędne do udzielania świadczeń zdrowotnych, wskazana przez kierującego działaniem ratowniczym.

30 Zob. rozporządzenie Ministra Spraw Wewnętrznych i Administracji z dnia 31 lipca 2001 roku w sprawie szczegółowych zasad kierowania i współdziałania jednostek ochrony przeciwpożarowej biorących udział w działaniach ratowniczych (Dz.U. Nr 82, poz. 895) i rozporządzenie Ministra Spraw Wewnętrznych z dnia 8 marca 2012 roku zmieniające rozporządzenie w sprawie szczegółowych zasad kierowania i współdziałania jednostek ochrony przeciwpożarowej biorących udział w działaniu ratowniczym (Dz.U. poz. 308).

${ }^{31}$ Kierowanie działaniami ratowniczymi prowadzone jest jednoosobowo przez uprawniona osobę odpowiednio i w widoczny sposób oznakowaną dla innych uczestników działań ratowniczych. Kierujący działaniem ratowniczym oddziałuje na podległe siły podmiotów systemu na miejscu zdarzenia, zgodnie z przyjętymi procedurami i planami ratowniczymi, w celu wykonania określonych czynności ratowniczych. 
towniczych na: interwencyjny, taktyczny i strategiczny wraz z przyporządkowaniem kompetencji do kierowania tymi działaniami na każdym z poziomów.

Biorąc pod uwagę, z jednej strony, powyższe definicje legalne akcji ratowniczej (działania ratownicze Państwowej Straży Pożarnej) i działań ratowniczych (każda czynności dla ochrony życia, zdrowia, mienia w obszarze niebezpiecznym) należy wskazać, że, z drugiej strony, ustawodawca wprowadza definicję legalną czynności ratowniczych przez ich wewnętrzną klasyfikację, w myśl § 2 pkt 1a-b rozporządzenia Ministra Spraw Wewnętrznych i Administracji w sprawie szczegółowej organizacji krajowego systemu ratowniczo-gaśniczego. Mianowicie ustawodawca dychotomicznie sklasyfikował czynności ratownicze na podstawowe, czyli czynności wykonywane w poszczególnych dziedzinach ratownictwa przez wszystkich ratowników oraz czynności ratownicze specjalistyczne, które zostały określone jako czynności wykonywane z użyciem sprzętu specjalistycznego przez odpowiednio przeszkolonych ratowników.

Stosownie do powyższych regulacji prawnych pod pojęciem akcji ratowniczych należy rozumieć działania ratownicze organizowane i kierowane przez Państwową Straż Pożarną, w zakresie zaś działań ratowniczych każdą czynność ratowniczą podstawową i specjalistyczną podjętą w celu ochrony życia, zdrowia, mienia lub środowiska, a także likwidacji przyczyn powstawania pożaru, wystąpienia klęski żywiołowej lub innego miejscowego zagrożenia.

Empiryczna eksplikacja zakresu obu definicji, to znaczy działania ratowniczego i akcji ratowniczej, wskazuje, że akcja ratownicza, według ustawowej definicji, ogranicza się do działań podejmowanych przez Państwową Straż Pożarną. W konsekwencji, w świetle ustawy o Państwowej Straży Pożarnej, podjęcie działań ratowniczych przez na przykład ochotnicze straże pożarne bądź inne straże pożarne nie będzie akcją ratowniczą. Odnosząc się do tego założenia, należy stwierdzić, że analiza zakresu pojęciowego terminu akcji ratowniczej i działań ratowniczych wprost prowadzi do wniosku, że szerszym katalogiem przedmiotowych przedsięwzięć charakteryzują się działania ratownicze zawierające w sobie zakres działań akcji ratowniczej przy jednoczesnej korelacji podmiotowej, ponieważ o ile organizacja i prowadzenie akcji ratowniczej są zadaniem komendanta powiatowego Państwowej Straży Pożarnej, o tyle prowadzeniem działań ratowniczych zajmują się jednostki ochrony przeciwpożarowej — w tym między innymi jednostki Państwowej Straży Pożarnej i ochotnicze straże pożarne, ale tylko ci strażacy ochotnicy (w przedziale wiekowym od 18 do 65 roku życia) tworzący strukturę jednostki operacyjno-technicznej ochotniczej straży pożarnej z przeznaczeniem do bezpośredniego uczestnictwa w działaniach ratowniczych. 


\section{Działania ratownicze podczas zdarzenia o charakterze terrorystycznym}

Kontekst wzrostu poziomu zagrożenia terrorystycznego - w perspektywie globalnej i krajowej, lecz także regionalnej, lokalnej i indywidualnej obywatela $\mathrm{RP}$ - uwarunkował konieczność wzmocnienia mechanizmów rozpoznawania, reagowania i skutecznej koordynacji działań licznych podmiotów, od służb mundurowych, organów administracji publicznej na poziomie krajowym, rządowym, przez władze lokalne (gminne), aż po sektor prywatny (w płaszczyźnie infrastruktury krytycznej) i całe społeczeństwa. Jedynie takie ujęcie systemowe (nie)bezpieczeństwa terrorystycznego bezpośrednio wpływa na szybkość i prawidłowość procesu decyzyjnego, od poziomu zapobiegania, rozpoznawania aż do samego przebiegu działań ratowniczych. Zasadność krajowych zmian legislacyjnych zmierzających do poprawy bezpieczeństwa związanego z tym zagrożeniem dotyczyła także zmian w ustawie o ochronie przeciwpożarowej ${ }^{32}$ oraz aktach wykonawczych ${ }^{33}$.

W katalogu działań wykonywanych w ramach krajowego systemu ratowniczo-gaśniczego należało uwzględnić przedmiotowe ryzyko, co skutkowało poszerzeniem zakresu działania Państwowej Straży Pożarnej o ratownictwo biologiczne w kontekście reagowania na zdarzenia terrorystyczne z wykorzystaniem czynników chemicznych, biologicznych, radiacyjnych i nuklearnych. W związku ze wskazanymi zmianami legislacyjnymi należy odnotować, że sam zakres zadań ochotniczych straży pożarnych w ramach akcji ratowniczych Państwowej Straży Pożarnej został rozszerzony do możliwości udziału strażaków ochotników w działaniach ratowniczych podczas zdarzenia o charakterze terrorystycznym, stosownie do brzmienia art. 24 ustawy o ochronie przeciwpożarowej w związku z $§ 16$ ust. 3 rozporządzenia Ministra Spraw Wewnętrznych i Administracji w sprawie szczegółowej organizacji krajowego systemu ratowniczo-gaśniczego. W sytuacji wystąpienia zdarzenia o charakterze terrorystycznym z użyciem czynnika biologicznego działania ratownicze obejmują $\mathrm{z}$ jednej strony wstępne sprawdzenie

32 Ustawodawca w art. 14 ust. 1a poszerzył zakres zadań Krajowego Systemu RatowniczoGaśniczego w ramach posiadanych sił i środków o współpracę z właściwymi organami oraz podmiotami podczas zdarzeń nadzwyczajnych wywołanych zagrożeniem czynnikiem biologicznym, w tym podczas zdarzeń o charakterze terrorystycznym.

${ }^{33}$ Na podstawie art. 63 ust. 3 ustawy z dnia 10 czerwca 2016 roku o działaniach antyterrorystycznych (Dz.U. z 2018 r. poz. 452 ze zm.) od dnia 3 lipca 2017 roku rozporządzenie Ministra Spraw Wewnętrznych i Administracji z dnia 18 lutego 2011 roku w sprawie szczegółowych zasad organizacji krajowego systemu ratowniczo-gaśniczego (Dz.U. poz. 239) utraciło moc prawną. Nowym aktem wykonawczym wydanym na podstawie delegacji ustawowej z art. 14 ust. 2 ustawy o ochronie przeciwpożarowej jest rozporządzenie Ministra Spraw Wewnętrznych i Administracji z dnia 3 lipca 2017 roku w sprawie szczegółowej organizacji krajowego systemu ratowniczo-gaśniczego (Dz.U. poz. 1319). 
niezidentyfikowanych przesyłek pod kątem możliwości wystąpienia zagrożenia biologicznego oraz ich zabezpieczenie, $\mathrm{z}$ wyłączeniem przesyłek o zagrożeniu wybuchowym; z drugiej strony do czynności tych należy też transport niezidentyfikowanych przesyłek potencjalnie stwarzających zagrożenie biologiczne w celu przeprowadzenia ich ostatecznej weryfikacji, jednocześnie czynności te mogą być realizowane tylko na wniosek Państwowej Inspekcji Sanitarnej Ministerstwa Spraw Wewnętrznych i Administracji we współpracy z kierującym działaniem ratowniczym.

\section{Wnioski de lege ferenda}

I - Rola jednostek ochrony przeciwpożarowej, a wśród nich przede wszystkim ochotniczych straży pożarnych wzmacniających działanie Państwowej Straży Pożarnej, jest kluczowa dla funkcjonowania państwa i społeczności lokalnych w sytuacjach ryzyka pożarowego oraz innych miejscowych zagrożeń. To właśnie jednostki Państwowej Straży Pożarnej i ochotnicze straże pożarne są w stanie działać podczas pożarów, klęsk żywiołowych czy miejscowych zagrożeń spowodowanych każdym czynnikiem. Jednocześnie należy wskazać, że jednym z istotnych warunków skutecznego działania jednostek ochrony przeciwpożarowej jest konieczność wspierania sił zawodowych i ochotniczych straży pożarnych przez działania administracyjno-prawne oraz skuteczną koordynację i współdziałanie podczas działań ratowniczych poszczególnych inspekcji i służb odpowiedzialnych za bezpieczeństwo wewnętrzne RP. Organizacja koordynacji i współdziałania jednostek ochrony przeciwpożarowej z innymi służbami i inspekcjami oraz organami administracji publicznej podczas działań ratowniczych wymaga prowadzenia i doskonalenia systemu ćwiczeń oraz szkoleń z zakresu nie tyle samego zarządzania kryzysowego, ile krajowego systemu ratowniczo-gaśniczego w zarządzaniu kryzysowym.

II - Współpraca jednostek organizacyjnych Państwowej Straży Pożarnej z miejscowymi jednostkami ochotniczej straży pożarnej kształtowana podczas działań ratowniczych bezpośrednio przyczynia się do skuteczniejszego przeci działania miejscowym zagrożeniom. W niektórych mniejszych gminach tylko dzięki działaniu ochotniczej straży pożarnej możliwe jest szybsze i skuteczniejsze zapobieganie zniszczeń materialnych powstałych w wyniku (nie)bezpieczeństwa pożarowego, a przede wszystkim racjonalna staje się ochrona poszkodowanego, jego życia i zdrowia, ponieważ zagrożenia mają charakter gminny, a nie powiatowy czy wojewódzki. Warto przypomnieć, że tylko ciągłe szkolenia prowadzone przez Komendy Powiatowe Państwowej Straży Pożarnej dla ochotniczych straży pożarnych prowadzą do podniesienia poziomu przeszkolonych strażaków ochot- 
ników, co z pewnością minimalizuje występowanie błędów i zmniejsza ryzyko wypadku przy prowadzonych działaniach ratowniczych.

III - Szczególnie istotne z punktu widzenia skuteczności ochrony przed (nie)bezpieczeństwami pożarowymi i innymi miejscowymi zagrożeniami dla całego systemu bezpieczeństwa publicznego RP jest zwrócenie uwagi na stan wyposażenia jednostki operacyjno-technicznej ochotniczej straży pożarnej. Ważne jest, aby stan ten wynikał bezpośrednio z analizy zagrożeń oraz analizy zabezpieczenia operacyjnego na obszarze powiatu i województwa, jak również planów ratowniczych. Samym już potwierdzeniem zapewnienia gotowości bojowej ochotniczej straży pożarnej musi być porozumienie zawarte pomiędzy gminą a ochotniczą strażą pożarną, poprzedzone porozumieniem w sprawie włączenia ochotniczych straży pożarnych do krajowego systemu ratowniczo-gaśniczego, na podstawie art. 20 ustawy o ochronie przeciwpożarowej i $\S 2$ rozporządzenia Ministra Spraw Wewnętrznych z dnia 15 września 2014 roku w sprawie zakresu, szczegółowych warunków i trybu włączenia jednostek ochrony przeciwpożarowej do krajowego systemu ratowniczo-gaśniczego (Dz.U z 2014 r. poz. 1317.) oraz uzgodnieniami z komendantem powiatowym Państwowej Straży Pożarnej, w trybie art. 19 ust. 3 ustawy o ochronie przeciwpożarowej.

IV - Właściwe przygotowanie do zapobiegania i zwalczania zagrożeń wymaga gotowości jednostek ochrony przeciwpożarowej rozumianej jako niezbędne siły i środki dla zabezpieczenia działań pożarniczych oraz ratowniczych na podstawie rozpoznania zagrożeń występujących na terenie operacyjnym, to jest na terenie chronionym, i na ryzyku, czyli prawdopodobieństwie i skutkach. Natychmiastowa reakcja na pojawienie się zagrożenia zależy w dużej mierze od zabezpieczenia logistycznego podmiotów krajowego systemu ratowniczo-gaśniczego. Samo zaś wyposażenie jednostek ratowniczych i ratowniczo-gaśniczych w odpowiedni sprzęt i kadrę najlepiej osiągnąć przez opracowanie i wykonanie zaawansowanego technologicznie narzędzia teleinformatycznego wspomagania i projektowania systemu ratowniczego na poziomie gminy, powiatu i województwa. Opracowanie metody, bazy danych, aplikacji i modeli wspomagających projektowanie zadań ratowniczych w praktyce pozwoli na zmniejszenie ryzyka narażenia życia i zdrowia, zmniejszenie szkód w sprzęcie, zwiększenie bezpieczeństwa funkcjonariuszy, zarządzanie alokacją sił i środków, wprowadzenie nowego standardu identyfikowania i inwentaryzowania zagrożeńn ${ }^{34}$.

34 P. Kępka, Projektowanie systemów bezpieczeństwa, Warszawa 2015, s. 214-216. Szerzej na temat znaczenia systemów teleinformatycznych dla zwiększenia poziomu bezpieczeństwa zob. referat G. Sobieraja Strategia rozwoju systemów teleinformatycznych KSRG wygłoszony 11 czerwca 2018 roku podczas konferencji naukowej „Ochotnicze Straże Pożarne — tradycja, samorząd, bezpieczeństwo" na Uniwersytecie Wrocławskim, Wydział Prawa, Administracji i Ekonomii, skonceptualizowany w artykule naukowym o tym samym tytule i opublikowany w dalszej części przedmiotowego wydania czasopisma „Prawo”. Dodatkowo w zakresie narzędzi i infrastruktury informatyczno-technicznej stosowanych przez jednostki ochrony przeciwpożarowej na przykładzie 
V - W zakresie wykonywania działań podczas akcji ratowniczej należy pamiętać, że (nie)bezpieczeństwa naturalne - pożary, powodzie, gradobicia i śnieżyce oraz inne ryzyka naturalne - nie znają państwowych granic terytorialnych, dlatego szczególnie istotne staje się podejmowanie współpracy w obszarach transgranicznych ${ }^{35}$.

VI - Rozwój (nie)bezpieczeństw cywilizacyjnych, a w tym nadzwyczajne zagrożenia terroryzmu, determinują konieczność przygotowania do prowadzenia działań ratowniczych nie tylko na skalę gminy, powiatu, województwa czy kraju, lecz również na skalę globalną. W okolicznościach, w których potencjał Państwowej Straży Pożarnej wspomagany działaniami ratowniczymi ochotniczych straży pożarnych okaże się niewystarczającym dodatkowym źródłem wsparcia, są możliwości współdziałania Sił Zbrojnych RP z zawodową strażą pożarną ${ }^{36}$ dla ochrony życia, zdrowia, mienia i środowiska w ramach powszechnego systemu ratowniczego.

Komendy Miejskiej Państwowej Straży Pożarnej w Wałbrzychu zob. szerzej K. Graczyk, G. Nakielski, T. Tabaczniuk, Elementy zarzadzania kryzysowego w administracji terytorialnej, Zielona Góra 2015, s. 133-143.

35 Jednym z przykładów wdrożenia skoordynowanych działań ratowniczych jest projekt „Bezpieczne Pogranicze Cz.11.1.23/0.0/0/0.0/15_001/0000006 Fundusz Mikroprojektów w Euroregionie Pradziad Programu INTERREG V-A Republika Czeska-Polska” będący efektem wieloletniej współpracy straży pożarnej z Polski i z Czech. Planowany czas trwania projektu to lata 2016-2019. Celem projektu jest podniesienie transgranicznej gotowości do podejmowania działań podczas rozwiazywania sytuacji kryzysowych poprzez wzmocnienie współpracy wszystkich służb odpowiedzialnych za bezpieczeństwo. W ramach konkretnych zamierzeń prowadzone są szkolenia językowe, konferencje, panele eksperckie, ćwiczenia ratownicze oraz zakupy sprzętu specjalistycznego. Zasadniczymi działaniami są analiza i ocena obecnego stanu prawnego i organizacyjnego w zakresie bezpieczeństwa na pograniczu, wzmocnienie systemu komunikacji, wymiany informacji i zarządzania w sytuacjach kryzysowych oraz podwyższenie stopnia kompatybilności systemów ratowniczych przy pożarach w ramach ratownictwa wodnego, powodziowego, przy wypadkach w komunikacji, w ratownictwie technicznym i ochronie środowiska, zob. szerzej www.bezpecnepohranici.eu/pl/ (dostęp: 10.07.2018) na temat uwarunkowań kierowania samą akcją ratowniczą zob. szerzej Z. Ścibiorek, Wybrane uwarunkowania kierowania akcja ratowniczą, [w:] Bezpieczeństwo w obszarach przygranicznych, red. B. Kaczmarczyk, t. 1, s. 233-251.

${ }^{36}$ Nota bene wnioski i postulaty zawarte w artykule S. Lipińskiego, Możliwości współdziałania Krajowego Systemu Ratowniczo-Gaśniczego i Sił Zbrojnych, [w:] Bezpieczeństwo obywateli w świetle reformy administracji rzadowej i samorzadowej - co dalej? Materiaty z konferencji naukowej, red. M. Lisiecki, Warszawa 2001, s. 94-105, w większości zostały zrealizowane w dokonanych zmianach legislacyjnych między innymi przez włączenie w struktury jednostek ochrony przeciwpożarowej jednostek organizacyjnych Wojskowej Ochrony Przeciwpożarowej, zgodnie z art. 15 pkt 1a ustawy o ochronie przeciwpożarowej. Szerzej na temat samego współdziałania Sił Zbrojnych RP z Państwową Strażą Pożarną zob. J. Falecki, Zarządzenie kryzysowe w teorii i praktyce, cz. 3, Relacje współdziałania, koordynacji działań, Sosnowiec 2014, s. 116-120. 


\section{Bibliografia}

Budzisz R., Ochrona przeciwpożarowa, [w:] Prawo administracyjne materialne, red. Z. Duniewska, B. Jaworska-Dębska, M. Stahl, Warszawa 2014.

Falecki J., Zarządzenie kryzysowe w teorii i praktyce, cz. 3. Relacje współdziałania, koordynacji działań, Sosnowiec 2014.

Gola G., Jednostki ochrony przeciwpożarowej w systemie bezpieczeństwa, [w:] Bezpieczeństwo wewnętrzne w działaniach terenowej administracji publicznej, red. A. Chajbowicz, T. Kocowski, Wrocław 2009.

Graczyk K., Nakielski G., Tabaczniuk T., Elementy zarzadzania kryzysowego w administracji terytorialnej, Zielona Góra 2015.

Grosset R., Poziom Powiatowy Krajowego Systemu Ratowniczo-Gaśniczego, Warszawa 2013.

Grosset R., Rola Krajowego Systemu Ratowniczo-Gaśniczego w systemie państwa, Warszawa 2011.

Gumieniak A., Owczarek L., Mochocki R., Bezpieczeństwo w wymiarze lokalnym. Wybrane obszary, red. M. Leszczyński, Warszawa 2013.

Kępka P., Projektowanie systemów bezpieczeństwa, Warszawa 2015.

Kierzkowska J.S., Wybrane aspekty prawne działalności tzw. , lotniskowych straży pożarnych” dla zapewnienia bezpieczeństwa działalności lotniczej w zakresie lotnictwa cywilnego, [w:] Dziatalność lotnicza w Polsce, red. K. Biskup, Z. Bukowski, Bydgoszcz 2015.

Kuczyński J., Ustawa o ochronie przeciwpożarowej z komentarzem, Warszawa 1970.

Kuczyński J., Zapobieganie pożarom. Zagadnienia prawne, Warszawa 1979.

Kurzępa B., Ustawa o ochronie przeciwpożarowej z komentarzem, Kraków-Tarnobrzeg 2010.

Leśniakiewicz W., Państwowa Straż Pożarna a Krajowy System Ratowniczo-Gaśniczy, Inowrocław 2010.

Lipiński S., Możliwości współdziałania Krajowego Systemu Ratowniczo-Gaśniczego i Sit Zbrojnych, [w:] Bezpieczeństwo obywateli w świetle reformy administracji rzadowej i samorzadowej - co dalej? Materiaty z konferencji naukowej, red. M. Lisiecki, Warszawa 2001.

Lis W., Bezpieczeństwo wewnętrzne i porządek publiczny jako sfera działania administracji publicznej, Lublin 2015.

Michalski M., Krajowy System Ratowniczo-Gaśniczy podstawa Państwowej Straży Pożarnej, Warszawa 2012.

Skoczylas J., Prawo ratownicze, Warszawa 2007.

Ścibiorek Z, Wybrane uwarunkowania kierowania akcja ratownicza, [w:] Bezpieczeństwo w obszarach przygranicznych, red. B. Kaczmarczyk, t. 1, Torun 2017.

Ura E., System prawny ochrony przeciwpożarowej w PRL, Warszawa 1981.

Warmiński A., Zadania i organizacja Państwowej Straży Pożarnej w zakresie ochrony przeciwpożarowej, „Doctrina Studia Społeczno-Polityczne” 2009, nr 6.

\section{Wykaz aktów prawnych}

Konstytucja RP z 2 kwietnia 1997 roku (Dz.U. z 1997 r. Nr 78, poz. 483 z późn. zm.).

Rozporządzenie Rady Ministrów z dnia 4 lipca 1992 roku w sprawie zakresu i trybu korzystania z praw przez kierującego działaniem ratowniczym (Dz.U. Nr 54, poz. 259).

Rozporządzenie Ministra Spraw Wewnętrznych i Administracji z dnia 14 września 1998r. w sprawie zakresu, szczegółowych warunków i trybu włączania jednostek ochrony przeciwpożarowej do krajowego systemu ratowniczo-gaśniczego (Dz.U. Nr 121, poz. 798). 
Rozporządzenie Ministra Spraw Wewnętrznych i Administracji z dnia 31 lipca 2001 roku w sprawie szczegółowych zasad kierowania i współdziałania jednostek ochrony przeciwpożarowej biorących udział w działaniach ratowniczych (Dz.U. Nr 82, poz. 895).

Rozporządzenie Ministra Spraw Wewnętrznych z dnia 7 czerwca 2010 roku w sprawie ochrony przeciwpożarowej budynków, innych obiektów budowlanych i terenów (Dz.U. Nr 109, poz. 719).

Rozporządzenie Ministra Spraw Wewnętrznych i Administracji z dnia 18 lutego 2011 roku w sprawie szczegółowych zasad organizacji krajowego systemu ratowniczo-gaśniczego (Dz.U. poz. 239).

Rozporządzenie Ministra Spraw Wewnętrznych z dnia 8 marca 2012 roku zmieniające rozporządzenie w sprawie szczegółowych zasad kierowania i współdziałania jednostek ochrony przeciwpożarowej biorących udział w działaniu ratowniczym (Dz.U. poz. 308).

Rozporządzenie Ministra Spraw Wewnętrznych i Administracji z dnia 15 września 2014 roku w sprawie zakresu, szczegółowych warunków i trybu włączania jednostek ochrony przeciwpożarowej do krajowego systemu ratowniczo-gaśniczego (Dz.U. poz. 1314).

Rozporządzenie Ministra Spraw Wewnętrznych i Administracji z dnia 3 lipca 2017 roku w sprawie szczegółowej organizacji krajowego systemu ratowniczo-gaśniczego (Dz.U. z 2017 r. poz. 1319).

Ustawa z dnia 4 lutego 1950 roku o ochronie przeciwpożarowej i jej organizacji (Dz.U. Nr 50, poz. 404).

Ustawa z dnia 13 kwietnia 1960 roku o ochronie przeciwpożarowej (Dz.U. Nr 20, poz. 120).

Ustawa z dnia 14 czerwca 1960 roku Kodeks postępowania administracyjnego (Dz.U. z 2017 r. poz. $1257 \mathrm{ze} \mathrm{zm}$.).

Ustawa z 12 czerwca 1975 roku o ochronie przeciwpożarowej (Dz.U. Nr 20, poz. 106).

Ustawa z dnia 7 kwietnia 1989 roku Prawo o stowarzyszeniach (Dz.U. z 2017 r. poz. 210 ze zm.).

Ustawa z dnia 8 marca 1990 roku o samorządzie gminnym (Dz.U. z 2018 r. poz. 994 ze zm.).

Ustawa z dnia 24 sierpnia 1991 roku o ochronie przeciwpożarowej (Dz.U. z 2018 r. poz. 620 ze zm.).

Ustawa z dnia 24 sierpnia 1991 roku o Państwowej Straży Pożarnej (Dz.U. z 2017 r. poz. 1204 ze zm.)

Ustawa z dnia 18 kwietnia 2002 roku o stanie klęski żywiołowej (Dz.U. z 2017 r. poz. 1897).

Ustawa z dnia 2 lipca 2004 roku o swobodzie działalności gospodarczej (Dz.U. z 2017 r. poz. 2486 ze zm.).

Ustawa z dnia 26 kwietnia 2007 roku o zarządzaniu kryzysowym (Dz.U. z 2017 r. poz. 209 ze zm.).

Ustawa z dnia 23 stycznia 2009 roku o wojewodzie i administracji rządowej w województwie (Dz.U. z 2017 r. poz. 2234 ze zm.).

Ustawa z dnia 10 czerwca 2016 roku o działaniach antyterrorystycznych (Dz.U. z 2018 r. poz. 452 ze zm.).

Zarządzenie nr 50/2008 Wojewody Dolnośląskiego z dnia 25 lutego 2008 roku w sprawie określenia zadań krajowego systemu ratowniczo-gaśniczego na terenie województwa dolnośląskiego.

Zarządzenie nr 51/2008 wojewody dolnośląskiego z dnia 25 lutego 2008 roku w sprawie określenia zakresu koordynowania przez wójta (burmistrza, prezydenta miasta) funkcjonowania krajowego systemu ratowniczo-gaśniczego na obszarze gminy. 


\section{Rescue actions of volunteer firefighters during rescue operations organised and managed by State Firefighters}

\section{Summary}

There are several kinds of entities responsible for fire protection strictly related to public safety of the Republic of Poland: public administration organs and specialised units. Furthermore, fire protection is provided by non-government organisations and citizens themselves. The latter associate as, for example, members of volunteer firefighters who gather deliberately to take civil responsibility for both individual and local safety risked by fire and other dangers. The aim of this paper is to present the legal aspects of volunteer firefighters rescue actions and to indicate their position and significance in operations organised and managed by State Firefighters to provide fire protection of the Republic of Poland.

Keywords: fire protection, volunteer firefighters, State Firefighters, rescue actions. 